\section{EIGHTEENTH SESSION OF THE INTERNATIONAL GEOLOGICAL CONGRESS}

$\mathrm{A}^{\mathrm{s}}$ $\mathrm{N}$ outline of plans for the eighteenth session of A the International Geological Congress was given in Nature, August 7, p. 232. The proceedings lasted in all for a period of seven weeks during August and September. Much of the time was occupied by a series of thirty-seven long geological excursions, which visited important localities throughout Great Britain and eastern Ireland. Some 250 British geologists acted as organisers, directors and secre. taries for these excursions and for an extensive series of additional short excursions centred on London. Despite indifferent weather, the excursion programme was extremely successful; it was clear that the excursion parties, which consisted predominantly of geologists from abroad, found interest and enjoyment in visiting the classic areas and type localities of the British Isles under the guidance of British specialists.

The formal and scientific meetings of the Congress, with an associated programme of receptions and entertainments, were held in South Kensington during August 25-September 1. The total membership of the session, including non-attending members, was more than 1,760 ; the total attendance of members and relatives was about sixteen hundred, including some nine hundred from overseas. Seventy. six different countries were represented; sixty-four Governments and 360 universities, societies and institutions sent official delegates.

This widely representative assembly provided the first full-scale opportunity for intermational geo. logical discussion for eleven years-since the seventeenth session in Moscow; and throughout the Congress members made good use of the opportunity. The attendance at all the meetings and functions was very large. At times five sectional meetings, each with an attendance of some two hundred members, were simultaneously in progress. Audiences of nine hundred filled the lecture theatre of the Royal Geographical Society to hear special addresses by Prof. O. T. Jones and Sir Edward Bailey on "The Structural History of Britain". Colour films of the Mexican volcano Paricutin, presented by Dr. J. G. Reyna and Dr. F. H. Pough, and of the Virunga volcanoes of Africa, presented by Prof. T. W. Gevers, were shown twice because the same theatre could not hold at one time all who wished to see them. More than fourteen hundred members attended a reception by H.M. Government on the first day of the session, and a similar number were present at a reception by the Geological Society on August 31 . Some six hundred official delegates and relatives were received by the Vice-Chancellor of the University of London on August 30, and many other receptions and entertainments were also successfully arranged. In addition to the formal items of the programme, members made full use for informal meeting and discussion of extensive lounge accommodation in the Geological Survey and Museum, which was the headquarters and registry of the Congress.

At the inaugural meeting in the Royal Albert Hall, Prof. H. H. Read, president of the Geological Society of London, was elected president of the Congress. Viscount Addison, Lord Privy Seal, welcomed the assembly on behalf of H.M. Government, and Sir John Anderson, honorary president of the General Organising Committee, explained how, under the ægis of the Geological Society and with active Government support through the Geological Survey and Museum, professional and amateur geologists throughout Britain had worked in face of considerable difficulties to make the Congress a success. From speeches by the heads of Government delegations at the final meeting of the general assembly on September 1, and from much informal comment, it can be judged that the delegates and members were, in fact, well pleased and satisfied with the arrangements which had been made.

During the session, the Council of the Congress arranged for the reconstitution of many of its international commissions, the work of which had been interrupted during the War. A full account of the proceedings of the Council, and of the sectional meetings, to which some 350 papers were offered, will be published in the report of the Session, but at least twelve months must necessarily elapse before this can be issued. Meanwhile, summaries of the more important decisions of the Council, and of the sectional proceedings, will appear in forthcoming numbers of the Geological Magazine. Further articles will also appear in Nature.

The Congress accepted with pleasure an invitation from the Government of France to hold the nineteenth session in Algiers in 1952. At the same time it expressed its gratitude for an invitation from the Government of India, and it is hoped that the invitation to meet in India may be renewed at the nineteenth session.

\section{SCHOOL OF PHARMACY, UNIVERSITY OF LONDON}

$T$ HE Dean of the College of the Pharmaceutical Society announced at the 107th inaugural meeting on October 6 that the College is to be reconstituted on an independent basis and renamed the School of Pharmacy, University of London. It will be financed mainly from University funds.

This event marks the end of a phase of pharmaceutical education in Britain which was identified with the efforts of the members of the Pharmaceutical Society, who from their foundation in 1841 proceeded energetically to raise the status of their calling by promoting a modern system of professional education. Their aim was reaffirmed in the charter which the Society obtained in 1843 , the objects of which included "the advancement of chemistry and phar. macy and the promotion of a uniform system of education". In pursuance of this policy the Society founded in 1842 what was at first known as the School of Pharmacy, the name being changed in 1926 to "The College of the Pharmaceutical Society".

The history of the School is a record of an attempt by a professional body to carry the burden of its own educational advancement, and all will join in paying tribute to the Society for success in that aim. The School from its inception has made outstanding contributions to our knowledge of pharmacy, chemistry, materia medica and medicine. The record of more than a century of endeavour is one which must redound to the credit of the Pharmaceutical Society. In 1842, with the prescience of enlightened educationists, the Society equipped and staffed a pioneer establishment on a scale which ultimately yielded rich dividends. A chemistry laboratory was established in that year which was one of the first of 
its type in Great Britain and which would at that time bear comparison with the best of its kind in Europe. It has housed a long list of distinguished professors, each of whom added an important quota to his science. Thus in chemistry we see the names Aufield, 1862 ; Tilden, 1865 ; Palmer Wynne, 1896; Collie, 1902 ; Crossley, 1904 ; and Dunstan, 1905; and in botany those of such figures as Robert Bentley, 1849, and Reynolds Green, 1887. In pharmacy and materia medica came Pereira, Redwood, Ince, Greenish and Wallis. The early days of the School saw the development of the use of the microscope by Greenish in the evaluation of powdered drugs. Its latter years saw the establishment, by Burn, of pharmacological laboratories for research work in methods of biological assays, and the years between had a record of steady achievement which was marked in 1926 by the recognition of the School by the University of London as a School of the University and by the establishment of a degree in pharmacy.

The reconstitution of the School brings to an end a fruitful regime of a hundred and six years, and inaugurates a new era which it is hoped to make even more productive of benefit to pharmacy than the old. Under its new title, the School will have an independent existence with a new governing body, a Council which will consist of the Dean (Prof. H. Berry), together with the following members: (a) nominated by the University of London: Dr. O. L. Brady, Sir Archibald Gray, Mr. John Hunter and Dr. G. B. Jeffery; (b) nominated by the Academic Board of the College: Prof. G. A. H. Buttle, Dr. Katharine Coward, Dr. J. W. Fairbairn and Prof. W. H. Linnell; (c) nominated by the Pharmaceutical Society: Mr. W. S. Howells, Mrs. J. C. Irvine, Mr. H. N. Linstead and Mr. C. W. Maplethorpe; together with three co-opted members : Sir Henry Dale, Mr. W. J. C. Quarrell and Sir Harry Jephcott, who becomes chairman of the new School Council. Mr. S. R. Curtis has been appointed secretary to the School.

\section{BRITISH EMPIRE CANCER CAMPAIGN}

$\mathrm{T}$ HE twenty-fifth annual report of the British Empire Cancer Campaign covers the work done during the latter half of 1947. To those not acquainted with the ramifications of modern cancer research, much of the work in the report will occasion surprise, owing to its apparent lack of connexion with the subject. But the fact is that the problem of malignant growth is inextricably bound up with peculiarities of cellular respiration, nutritional requirements, hormone balance and interaction of enzyme systems; and its study demands contributions from almost every branch of science.

In the sphere of radiation physics, work has been mainly concerned with preparing the way for the future use of high-voltage radiation and of radioactive isotopes. To this end refinements of methods for accurate measurement of dosage, which becomes of increasing difficulty and importance under these conditions, have been developed. Measurements of extraneous radiations likely to harm personnel engaged in radiation therapy have also been carried out. During the year, further studies have been made on the biological effects of radiations. The extreme rapidity with which cellular changes occur is astonishing. Thus Prof. J. S. Mitchell has shown that within seven minutes of exposing cultures of chick embryo fibroblasts to $\mathrm{X}$-irradiation, alterations occur in the amount of substances in the cells which cause absorption of ultra-violet light of wave-length 2537 A. Ribose nucleic acid is believed to be largely responsible for such absorption; but the possibility that other substances may be concerned is receiving attention. By standard histological methods pyenotic changes in the cell nuclei of the membrana granulosa of large ovarian follicles can be demonstrated within four hours of irradiating rats (L. Halberstaedter and M. Ickowicz). By the use of radioactive phosphorus $\left(\mathbf{P}^{32}\right)$ uptake as a measure of thymonucleic acid formation, Mrs. B. E. Holmes has adduced evidence that therapeutic doses of X-rays reduce the synthesis of this substance, and that this reduction may be an integral part of the damaging effects of radiations. On the clinical side, an important practical outcome of A. Glücksmann and L. G. Spear's histological method of assessing the progress of radiation therapy in cancer of the cervix uteri has been that, on the strength of it, several cases have been submitted to radical surgery, irradiation having been abandoned although in some cases the clinical response seemed favourable. In every case examination of the operation specimens showed the malignant process to be active.

Among the clinical reports is an analysis from Birmingham of survival-rates of 1,367 cases of cancer of the breast observed between 1936 and 1942. The accepted clinical opinion that the results of surgery combined with radiotherapy are superior to those of either form of treatment alone receives statistical confirmation. Owing to the small numbers, however, it is not possible to decide whether pre-operative or post-operative irradiation is the more effective method; though in the series quoted, post-operative treatment gave the better results. From St. Mark's Hospital come some important figures relating to cancer of the rectum. Of 716 cases treated between 1928 and 1941, just under half survived five years or more. But the five-year survival-rate of cases with disease confined to the rectum was more than 80 per cent, whereas those in which lymphatic metastases were present had a five-year survival-rate of just over 25 per cent. The correlation between the histological appearance of the growths and the extent of metastases was high in this series. Lymph. atic spread was present in 80 per cent of cases in which 'high grade' malignancy was reported histologically; but in only 20 per cent of those reported as 'low grade'. In a very full report by the Clinical Cancer Research Committee on malignant disease of kidney, bladder and prostate, the figures concern cases treated before oestrogen therapy had been introduced for the last-named disease, and will therefore be useful for comparison with similar figures when the results of such treatment are available.

Sir Ernest Kennaway's study of the effect of circumcision on the subsequent development of cancer of the penis has already excited comment in the medical Press. He finds that the operation protects against eancer if performed at eight days, but confers no protection when carried out after the fourteenth year. "The failure of the operation deferred until the 14th year to give the protection given by it when carried out on the 8 th day suggests that the train of events leading to malignant growth is set going early in life, and that removal of the cause 